\title{
Macroeconomic imbalances, financial stress and fiscal vulnerability in the euro area before the debt crises: A market view
}

\author{
Gilles Dufrénot ${ }^{\mathrm{a}}$, Karine Gente ${ }^{\mathrm{b}, *}$, Frédia Monsia ${ }^{\mathrm{b}}$ \\ a Banque de France, CEPI, Aix-Marseille University, Aix-Marseille School of Economics, CNRS \& EHESS France ${ }^{\text {b }}$ Aix-Marseille \\ University, Aix-Marseille School of Economics, CNRS \& EHESS, France
}

A B S T R A C T

This paper tries to identify the macro-financial imbalances that exposed the euro area countries to fiscal stress before the out-break of the European debt crises. Contrary to conventional wisdom that interprets fiscal stress in terms of fiscal sustainability, we focus on short-term fiscal vulnerability as reflected by the conditions of debt refinancing in the sovereign bond markets. We find that market-based indicators capturing risk perceptions of sovereign debts have been influenced by the indicators defined in the European Macro-economic Imbalance Procedure (MIP) and by variables of financial vulnerability. When pricing the risk of sovereign bonds, the holders of government debts take into account not only the macroeco-nomic imbalances but also factors such as banking distress, corporate bond risk, liquidity risks in the interbank market or the volatility of stock prices.

Keywords: Fiscal vulnerability, Euro area, Leading indicators, Macro-financial imbalances Signal models, Probit models

JEL Classification: C23 E44 F34 G12 H63

* Corresponding author. Chateau Lafarge, GREQAM, Route des Milles, 13290, Aix-en-Provence Les Milles, France. Tel.: +33442935960.

E-mail address: karine.gente@univ-amu.fr (K. Gente). 


\section{Introduction}

Following the height of the European debt crises from 2012 onward, concerns have risen about the global nature of these crises. Rather than focusing on debt ratio and fiscal balance alone, the European Commission has set up a scoreboard of indicators that defines the "Macroeconomic Imbalance

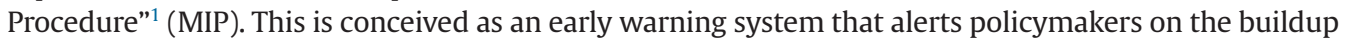
of macroeconomic imbalances. The variables defining the MIP are designed to provide an early detection of fiscal stress in the euro area countries. Policymakers consider that the debt crises in European countries have been brought by the vulnerabilities associated with the current account imbalances, lack of price competitiveness, over-indebtedness in the private sector, weak economic growths. This view is echoed in recent empirical papers. For instance, Berti et al. (2012) and Hernández de Cos et al. (2014) show that some of the MIP indicators provide a good explanation of fiscal vulnerability in the European countries. Their approach goes beyond the paper of McHugh et al. (2011) and Dobrescu et al. (2011) which focus on fiscal variables alone as a source of fiscal stress.

Our paper looks back in time (before 2012 onward, the years corresponding to the height of the debt crises in Europe). Macroeconomic imbalances had already risen concerns among investors in the sovereign bond markets, in spite of the fact that they were not yet incorporated in the multilateral surveillance mechanism by policymakers. The markets' view of fiscal vulnerabilities differs from the policymakers'. The latter seek to keep sovereign debt sustainable over a medium-to-long-term horizon. In contrast, the former have short-term motivations and pay attention to whether governments service their debt in due time, whether they face credit or illiquidity risks. The markets' view needs to be taken into account in the exercise of monitoring fiscal vulnerabilities for several reasons. Firstly, governments can face more stringent financing constraints that degenerate into a future debt crisis. Secondly, since sovereign debts are financed in the bond markets, investors pay attention to the share of interest in the governments' fiscal revenues (interest burden). A large share increases the probability that a government faces a higher liquidity risk on debt coming due. Thirdly, the exposition to sovereign debts in the euro area concerns both sovereign and private lenders. The recent experience of the Greek default suggests that private investors are the front runners in the debt crises. Markets' sentiments can therefore alert the policymakers about forthcoming debt vulnerability.

Against this background, this paper suggests that policymakers should make their judgment about their fiscal vulnerability by monitoring "market-based" indicators.

The recent literature resurrected the idea that fiscal stress and fiscal vulnerability in Europe were the consequence of adverse market participants' sentiment, thereby implying too high sovereign rate spreads compared with their "fundamental" value (see, Aizenman et al., 2013; Borgy et al., 2014; De Grauwe and Ji, 2013; Saka et al., 2015). Therefore, there is a need to consider variables of fiscal vulnerability reflecting markets' sentiment.

Our contribution to the existing literature is threefold.

The paper's first contribution is to interpret fiscal stress as the result of investors' behavior in the bond markets (rather than in terms of fiscal sustainability). We do not consider fiscal stress as reflecting "extreme" situations like a risk of default, debt restructuring, or debt unsustainability. Here, fiscal stress is understood as a worsening of the financing conditions in the sovereign bond markets." 2

The second contribution of the paper concerns the variables used as advanced indicators of fiscal stress. A first set of variables includes macroeconomic variables that have been already used in the recent literature. The MIP indicators are considered to summarize different facets of macroeconomic imbalances: competitiveness, private sector indebtedness, potential bubble in asset markets, fiscal and current account imbalances, etc. In addition to these variables, we consider financial stress indicators.

Our paper intends to examine which types of financial stress can be associated with higher fiscal vulnerability. The next section provides all the details about the choice of these financial variables.

Our third contribution concerns the methodology. A methodology which is common in the literature addressing the fiscal stress issue in Europe is the non-parametric signals approach (Berti et al.,

1 The new Excessive Imbalance Procedure (EIP) was set up in November 2011 in EU Regulation 1176/2011.

2 For robustness, we consider different measures of fiscal stress. These variables are extensively described in the next section. 
2012; Dobrescu et al., 2011; McHugh et al., 2011). It consists in examining (i) which variables send a signal prior to a fiscal stress event and (ii) the state of the economy and financial markets in which a fiscal distress is triggered. The advantages of the signal-based approach are its simplicity and parsimony (in the sense that this method does not require minimum number of observations with a "1" value in the dependent variable, or a minimum number of explanatory variables). Meanwhile, it does not lead to an analysis of the significance of the variables' influence. Neither does it take into account correlations between the variables. Another widely used approach is the logit/probit model. Many works have been proposed using this model with regard to different types of fiscal stress, but little on the link between fiscal stress and its determinants in Europe. This paper adopts both approaches to account for different features in the data.

The signals approach can be viewed as a first step in order to obtain a ranking of the variables that are likely to pre-announce a fiscal stress. Then, one needs to get an idea about the "confidence" of the predictions. The logit/probit models are helpful since they give information about the marginal effect of a change in a given variable on the probability of fiscal vulnerability. Unlike the previous literature using this type of models to predict fiscal stress, we report estimates based on random error component models rather than on pooled models.

The findings of this paper highlight the importance of capturing fiscal vulnerability through the investors' perception of fiscal risk (as reflected by price bond convexity, duration, skewness and kurtosis). It seems that they pay attention to "small" macroeconomic imbalances. This is seen from different threshold values obtained for the explanatory variables leading to fiscal vulnerability. This result accords with the so-called wake-up calls view by which investors in the markets are very sensitive to changes in macro-financial imbalances during times of fiscal vulnerability (the interesting feature is that we find such a sensitive reaction even during non-crisis periods since our data cover the years before the 2012 European debt crises).

Secondly, it is also apparent from our results that a fiscal stress episode does not depend upon the state of the previous period. This finding accords with the common wisdom idea that corrections of macro-financial imbalances were not systematically enacted when the vulnerability of public finances were in doubt. Even when higher financial stress and worse macroeconomic conditions put further strain on government finances, fiscal policies were not necessarily successful in bringing about a reduction of fiscal stress.

A third finding of the paper suggests that, when evaluating the marginal effects of the determinants of fiscal vulnerability, controlling for the influence of financial markets stress on fiscal vulnerability improves strongly the predictive accuracy of fiscal stress events. Comparing our best models with FSI variables with the models with only the MIP variables leads to drastic changes in the value and significance of some variables. This could mean that regressions with only the macro-financial imbalances of the MIP would suffer from omission bias.

The remainder of the paper proceeds as follows. Section 2 provides a brief overview of the literature on the source of fiscal vulnerability in the euro area and the details about the choice of variables. Section 3 presents our early warning signals model of fiscal stress. Section 4 presents the data and discusses our main findings with signals approach. Section 5 contains our estimations of probit models. Section 6 concludes.

\section{Choice of the variables and related literature}

While this paper attempts to empirically identify variables that can presumably be considered as early signals of fiscal vulnerability ${ }^{3}$ (or fiscal stress) in the short-term, our choice of the endogenous and exogenous variables is motivated by an existing literature suggesting a handful of variables whose informational content can help predict sovereign spreads, the dynamics of debt service and the pricing of sovereign credit risks.

\footnotetext{
3 Throughout this paper, though the literature sometimes distinguishes between fiscal stress and fiscal vulnerability, we shall use both terms interchangeably.
} 
First, we define a situation of fiscal stress as a context of sovereign risk in the short-term, as perceived by the sovereign bonds holders ("the markets"). Several measures of such a risk have been proposed in the literature. Common variables used are the sovereign rate spreads, the CDS spreads, the interest burden to fiscal revenues ratio, risk-premia. In the wake of both the 2009 financial crisis and the European debt crises that erupted in the mid-2011, the recent literature has been concerned with improving the understanding of the main determinants of sovereign spreads in the euro area. The backbone of the paper is the identification of indicators susceptible to pre-announce fiscal stress and the channels that are likely to amplify unseen precursor imbalances. Though our paper is not concerned with fiscal crises, we wonder whether the identified determinants of the latter also contain information about fiscal vulnerability/stress reflected by more stringent short-term refinancing in the sovereign markets. In this respect, we briefly review the main arguments provided in the literature to explain the dynamics of the euro area spreads and the pricing of sovereign risk in the euro area.

The theoretical workhorses in the analysis of sovereign spreads are threefold. Firstly, the empirical models are consistent with international asset pricing models of market integration or segmentation à la Barr and Priestley (2004). Secondly, credit risk models based on Cox-Ingersoll-Ross diffusion equations have also proved useful to derive the market price of sovereign bonds (see, for instance, Pan and Singleton, 2008). Thirdly, market price of sovereign risks is modeled as term premia and interest rates from affine models à la Vasicek (1977), Duffee (2002) and Duffie and Singleton (1999). However, in order to demonstrate how different factors affect fiscal stress, the bulk of the literature has focused on empirical approaches and the estimated equations can be considered as reduced form of these theoretical models. $^{4}$

The main conclusions that can be drawn from the abundant empirical literature are the following. (i) Sovereign debt markets react to a multitude of fundamental factors when investors penalize for the yields. The financing cost of new debt depends on fiscal imbalances (public debt ratio, primary deficit), external sector vulnerabilities (current account deficits, competitiveness, exchange rate overfluctuations), financial market risks (credit and liquidity risks, bank risks), global macroeconomic environment (inflation, growth, foreign spreads). (ii) Bond liquidity premium depends on market sentiment and market microstructure (self-fulfilling expectations, transaction costs, investment opportunities). (iii) The literature is still inconclusive about the factors which can be considered as the dominant drivers of sovereign spread (macroeconomic fundamentals, financial conditions, international common risk factors, or the risk-taking behavior in the markets). One reason is that the different factors alter in sovereign risk pricing over time. (iv) A sizable share of spread fluctuations is liquiditydriven. (v) Before the debt crises, sovereign debt risks were under-estimated by the markets.

Aside from the 2008 financial crisis and the height of the European debt crises, the euro area countries have experienced few fiscal crises since 1999 (in the form of debt default, debt restructuring and rescheduling, fire sales in the sovereign bond markets). However, periods of fiscal stress/vulnerability have occurred more frequently involving changes in spreads and prices beyond a certain "normal threshold" (not necessarily corresponding to abrupt changes). Such periods can be thought of as times of "market pressure." In this paper, we use market indicators about fiscal vulnerability reflected by the re-financing conditions of public debts. We wonder whether the usual determinants of sovereign spreads in the literature are suggestive of an important role for macroeconomic imbalances and financial vulnerabilities in causing sovereign debt market pressure. Common with the usual literature is our choice of sovereign spreads as a first measure of such a pressure. We, however, go beyond, by considering additional indicators of market pressure on sovereign bond markets.

We consider the interest paid to sovereign debt holders, as share of fiscal revenues. This measures how large is the fiscal income raised by a government in excess of the debt interest payments to the holders of public bonds. Credit rating agencies, which influence the investors' perception of sovereign risk, use this variable to make a judgment on the likelihood that a country will or will not easily

\footnotetext{
${ }^{4}$ For recent contributions, the reader can refer to Afonso et al. (2012), Afonso et al. (2015), Afonso and Nunes (2015), Aizenman et al. (2013), Beirne and Fratzscher (2013), Bernoth et al. (2012), De Santis (2014), Dötz and Fischer (2010), Ejsing and Lemke (2011), Erce (2015), Fontana and Scheicher (2010), Gibson et al. (2014), Heinz and Sun (2014), Mink and De Haan (2013), Maltritz (2012), Monfort and Renne (2014), and Von Hagen et al. (2011).
} 
meet its financial commitments. An increase in this ratio is generally interpreted as a sign that government fiscal resources will not necessarily be forthcoming to make interest payments timely. If the agencies rating worsens, then the investors' appetite to hold foreign debt may wane, thereby implying higher pressures on the risk-premia and therefore higher fiscal vulnerability. To the best of our knowledge, the ratio of debt repayments to fiscal revenues has been widely used to study fiscal risk in the emerging and developing countries, but not on the European industrialized countries which were not supposed, until the 2011 debt crises, to face illiquidity problems to refinance their debt. We try to fill this gap by interpreting fiscal stress/vulnerability as a situation in which a government is not fiscally healthy enough to pay back the debt interest.

We additionally consider two measures of bond risks as reflected by the curvature of the priceyield curve. Specifically, we measure the attractiveness of sovereign bonds by bond price duration and convexity. Our idea is that market pressure may illustrate the degree of exposure of bond holders to shifts in interest rate spreads.

Besides, the vulnerability of sovereign bond markets relates to the bond return distribution. Large negative excess returns are more likely in less liquid markets. Large increases in spreads are more likely than sharp declines (or vice-versa) for several reasons: positive and negative events do not have the same informational content for investors, the diffusion of news spillover in the sovereign debt markets occurs in an asymmetric manner: some price changes are muted while others are accentuated. Thick and fat tails are also likely to characterize bonds, just as they describe the distribution of equities. The distribution of sovereign spreads and sovereign bond prices influence the financing of governments' debts, because they have implications for asset pricing and risk management (investors' price skewness and kurtosis ${ }^{5}$ ). The above arguments suggest that fiscal stress/vulnerability conveyed by the markets could be investigated by considering the skewness and kurtosis of sovereign bond prices.

Our selection of explanatory variables (the determinants of fiscal vulnerability) is based on the recent literature examining the leading indicators of fiscal stress in the European countries (Berti et al., 2012; ECB, 2014; Hernández de Cos et al., 2014). Both macroeconomic and financial imbalances are now considered as potential factors of budgetary risks in Europe and have been integrated in the European system of multilateral budgetary surveillance. So far, the focus has been on the implications for fiscal sustainability and fiscal crises. But the global imbalances could also be factors of short-term refinancing vulnerability. In this paper, two types of variables will serve as indicators for identifying fiscal vulnerability. As first possible determinants, we consider the Macroeconomic Imbalances Procedure (MIP) indicators. They form the macroeconomic fundamentals used in the most recent studies within a European context. As shown by Table 1, the variables that can trigger fiscal stress relate to imbalances in external sector, imbalances in the real estate and private sectors, and financial market vulnerabilities.

We enlarge the set of financial variables considered by the MIP, which focuses on private sector indebtedness and house price increases. Broader financial market situation needs to be taken into account: buildup of vulnerabilities in the banking sector, price fluctuations in exchange rate and stock markets, funding difficulties in corporate bond markets. We draw from a rapidly growing literature examining the fiscal costs of financial distress. Papers investigate the fiscal impact of the banking sector vulnerabilities, the collapse in tax revenues in the wake of financial crises leading to downturns, the consequences of financial imbalances in terms of higher debt ratio. ${ }^{6}$ Our choice of financial stress indicators reflects the choice of similar variables in the literature. In detail, we consider corporate bond spreads, beta of the banking sector, inverted term spread and ted spread, volatility of nominal exchange rate and stocks markets.

\footnotetext{
5 There is a vast literature in finance relating portfolio optimization and selection to higher moments than the first two in the distribution of asset prices. Utility maximizing portfolio models incorporates preference for kurtosis, kinked utility functions in which investors favor or dislike skewness and kurtosis.

${ }^{6}$ See Andritzky (2012), Arslanalp and Poghosyan (2014), Gray (2013), Reinhart and Rogoff (2011), and Tagkalakis (2014).
} 
Table 1

Description of MIP indicators.

\begin{tabular}{|c|c|}
\hline MIP Indicators & Transformation formula \\
\hline Current account balance (CA) & $\begin{array}{l}3 \text { year backward moving average of the CA in } \% \text { of GDP, } \\
\text { threshold: lower bound: }-4 \% \text {, upper bound: } 6 \%\end{array}$ \\
\hline Nominal unit cost of labor (NULC) & $\begin{array}{l}3 \text { years \% change in NULC, threshold: } 9 \% \text { for euro area } \\
\text { countries }\end{array}$ \\
\hline Export market shares & $\begin{array}{l}5 \text { years \% change of export (share of world exports), } \\
\text { threshold: }-6 \%\end{array}$ \\
\hline Real effective exchange rate (REER) & $\begin{array}{l}3 \text { years \% change of the REER ( } 15 \text { European countries) } \\
\text { based on double export weights deflators, threshold+ } \\
\text { or }-5 \% \text { for euro area countries }\end{array}$ \\
\hline Private sector debt & Private sector debt in \% of GDP, threshold: $133 \%$ \\
\hline Private sector credit flow & Private sector credit flow in \% of GDP, threshold: $15 \%$ \\
\hline Public debt & $\begin{array}{l}\text { General government sector debt in \% of GDP, } \\
\text { threshold: } 60 \%\end{array}$ \\
\hline Real House price index (HPI) & $\begin{array}{l}\text { Year-on-year change in deflated house prices, } \\
\text { threshold: } 6 \%\end{array}$ \\
\hline Unemployment rate & $\begin{array}{l}3 \text { year backward moving average of unemployment } \\
\text { rate, threshold: } 10 \%\end{array}$ \\
\hline
\end{tabular}

\section{An early warning model of fiscal stress in the euro area}

The design of an early warning signal model requires considering several (4) steps. Firstly, we define fiscal stress episodes. Secondly, we define the explanatory variables (the "indicators"). Thirdly, we estimate threshold values on these indicators to define when they can issue a signal of fiscal stress. Fourthly, we aggregate the different indicators into a composite early warning global indicator (called "index"), and we estimate threshold values above which these aggregate variables signal a situation of fiscal stress. All these steps are described in detail below.

\subsection{A definition of fiscal stress episodes}

A situation of fiscal vulnerability occurs when a government faces a risk not to be able to service its debt. We adopt the ECB (2014)'s approach, according to which fiscal stress can be defined as the short-term risk of facing a sovereign liquidity crisis. In this paper we consider several variables that capture the cost of short-term financing of new debts and the price of sovereign bonds in the secondary markets. We use six variables of fiscal stress: sovereign bond spreads, year-on-year change in the sovereign yield as share of fiscal revenue and four variables of bond price reaction to interest rate change in the bond markets.

Sovereign bond spreads are commonly used in the literature to capture fiscal vulnerability since they release information about risk-premia and any penalization for the yields. We define:

$$
B S_{t}^{i}=r_{t}^{i}-r_{t}^{U S}
$$

where $B S_{t}^{i}$ and $r_{t}^{i}$ are respectively country $i$ 's sovereign bond spread and bond yield at time $t, r_{t}^{U S}$ is the US bond yield at time $t$ (the latter is considered as the benchmark rate to compare the European countries' spreads).

A second variable relates to how burdensome service of debt is for public finance. This is the debt burden to tax revenue ratio:

$$
D B R_{t}^{i}=\operatorname{DebtBurden}_{t}^{i} / \operatorname{Rev}_{t}^{i}
$$

where $\operatorname{Rev}_{t}^{i}$ is the fiscal income in country $i$ at time $t$. The debt burden ratio $D B R$ is defined as the interest payments (DebtBurden) as a share of fiscal revenues. We define the year-on-year change of debt burden to fiscal income ratio as: 


$$
\operatorname{Yoy}_{D B R_{t}^{i}}=\frac{\left(D B R_{t}^{i}-D B R_{t-1}^{i}\right)}{D B R_{t-1}^{i}} * 100
$$

Next, we consider two measures of risk for a sovereign bond. The average term in which a government must face its debt service is captured by bond duration and convexity. Fiscal vulnerability is therefore captured by the impact on prices that are the result of interest rate changes, or how much the value of bond will change following a $\mathrm{x} \%$ interest rate variation. Since duration is valid only for infinitesimal changes in yields, we also consider convexity which is a better indicator of the curvature of the relationship between prices and yields when there are large shocks. We define:

$$
D_{t}^{i}=-\frac{1}{P_{t}^{i}} \frac{\Delta P_{t}^{i}}{\Delta r_{t}^{i}}
$$

and

$$
C_{t}^{i}=-\frac{1}{P_{t}^{i}} * \frac{\Delta^{2} P_{t}^{i}}{\Delta r_{t}^{i^{2}}}
$$

where $D_{t}^{i}$ and $C_{t}^{i}$ are respectively the duration and convexity of a sovereign bond price $P_{t}^{i}$ at time $t$.

We finally consider two proxies for credit risk. The issuer credibility is not the same when negative variations in bond prices arise and when prices go up. Besides, losses in bond portfolios are more likely during extreme stress events. For this reason, the expected yield depends on the distribution of bond prices. We therefore consider both the skewness and kurtosis of bond prices.

To detect episodes of fiscal stress, we define a signal variable denoted by $S_{t}^{i j}$, where $i=1, \ldots, 8$, denotes the country, $j=1, \ldots, 6$, denotes the type of endogenous variable considered (BS, Yoy ${ }_{D B R}, D, C$, skewness and kurtosis of bond prices), and $t$ the period such that

$$
S_{t}^{i j}= \begin{cases}1, & \text { if } y_{t}^{i j} \geq c^{i j} \\ 0, & \text { otherwise }\end{cases}
$$

with the threshold $c^{i j}$ given by

$$
c^{i j}=\mu^{i j}+\lambda \sigma^{i j}
$$

where $\mu^{i j}$ and $\sigma^{i j}$ are respectively the mean and the standard error of the endogenous variable $y_{t}^{i j}$ which stands alternatively for the different measures $j$ of the fiscal stress in country $i$. $\lambda$ is an arbitrary weight whose choice that involves a trade-off. The selection must be done taking into account a compromise between obtaining too many or to few values of 1 . On the one hand, one might be looking for some values that do not "smooth out" the information on the occurrence of fiscal stress episodes (which happens with large values of $\lambda$ ). On the other hand, we want to reduce the number of "false" signals of fiscal vulnerability (that happens with small values of $\lambda$ ). Therefore, we may need to contend ourselves with a "suboptimal" choice of this parameter. To reduce this caveat, we compare the obtained values 1 with the occurrence of "effective" vulnerability situations defined as a period in which the rating agency Standard and Poor's downgraded a country domestic currency, though we are well aware that these downgrades are not indisputable. The best fit is obtained with $\lambda=0.5$. For purpose of robustness, we also examined the frequency of fiscal stress episodes for other values of $\lambda=0.5(\lambda=1$, $\lambda=1.5$ ). The results are available upon request to the authors.

\subsection{Explanatory variables used for the early detection of fiscal stress}

We consider 9 indicators of the European Commission (EC) MIP scoreboard (see Table 1). Here, we do not consider the EC's thresholds but we estimate them endogenously. 
A first set of indicators refers to external imbalances with the current account balance. A second set of variables reflects the competitiveness of the country (export market share, nominal unit labor costs and real effective exchange rate). A third set of indicators concerns internal imbalances, based on private sector debt, public debt, private sector debt flow, changes in the house price index and unemployment rate. These indicators reflect "global" imbalances that could be potentially harmful for public finance and induce fiscal vulnerability. An additional indicator concerns the financial sector liabilities. The latter will be replaced here by other financial variables that cover different aspects of financial stress.

The financial stress indicators we consider are taken from Balakrishnan et al. (2011) and Lall et al. (2009). These indicators capture health of the banking system (beta of banking sector ${ }^{7}$ and Inverted yield spread ${ }^{8}$ ), large asset prices shifts (stock market returns), abrupt risk/uncertainty increases (stock and foreign exchange volatility ${ }^{9}$ ), abrupt liquidity shifts (treasury eurodollar (or ted) spreads ${ }^{10}$ ) and corporate bond spread. ${ }^{11}$ For a detailed description of the indicators, see Table A1.

\subsection{Computation of the critical thresholds}

Using a standard nonparametric signal approach, we want to see which of the MIP and FSI variables would have been useful for detecting fiscal vulnerability episodes, if had they been used in the past years, before the height of the European debt crisis in 2012. To compute the threshold values of these variables that trigger a vulnerability or stress signal, we consider the different (10) quantiles of their distribution and we define, for each quantile $q$, type I (false positive: false stress periods) and type II (false negative: missed stress periods) errors.

We first compute the following set of indicators for each endogenous variable $j$ and each exogenous variable $k$ :

- $T P_{q k}^{j}$ : true positive. The explanatory variable signals a fiscal stress that indeed occurs;

- $F P_{q k}^{j}$ : false positive. The explanatory variable signals a fiscal stress that never occurs;

- $T N_{q k}^{j}$ : true negative. The explanatory variable does not signal the occurrence of a fiscal stress, and no fiscal stress is observed;

- $F N_{q k}^{j}$ : false negative. The explanatory variable misses a fiscal stress that occurs.

Secondly, we compute the noise-to-signal ratio (NSR) and the total misclassified errors ( $\mathrm{TME}^{12}$ ) according to:

$$
N S R_{q k}^{j}=\frac{F P_{q k}^{j} / N f_{q k}^{j}}{T P_{q k}^{j} / F S_{q k}^{j}}
$$

and

$$
T M E_{q k}^{j}=\frac{F P_{q k}^{j}}{N f_{q k}^{j}}+\frac{F N_{q k}^{j}}{F S_{q k}^{j}}
$$

\footnotetext{
7 The Beta of the banking sector captures the relative banking sector risk.

8 Inverted term spread defines a situation in which the difference between the long-term and the short-term yields on financial instrument is negative.

${ }^{9}$ Higher volatility is a sign that markets are nervous.

${ }^{10}$ The ted spread measures the pressure on the interbank markets (proxy for counterparty risk). It is an indicator of creditworthiness and interbank market liquidity.

${ }^{11}$ Defined as the gap between corporate bond yields and long-term government bond yields. This indicator is used as a proxy of corporate debt market risk.

12 TME approach consists in computing the sum of type I and type II errors.
} 
where $F S_{q k}^{j}=T P_{q k}^{j}+F N_{q k}^{j}$ represents the total number of fiscal stress episodes recorded in the data and $N f_{k}^{j}=F P_{q k}^{j}+T N_{q k}^{j}$ is the number of "no-fiscal" stress recorded in the data. Thirdly, we select, for each explanatory variable $k$, the optimal quantile as the quantile $q$ at which the NSR is minimal and/or the quantile at which the TME is also minimal. ${ }^{13}$ Let $x^{k}$ denote the exogenous variable of type $k$ and $Z_{q}^{j k}$ be a variable such that

$$
Z_{q}^{j k}= \begin{cases}1, & \text { if } x^{k}>x_{j q}^{k} \\ 0, & \text { otherwise }\end{cases}
$$

where $x_{q}^{k}$ represents the quantile $q$ of the exogenous variable $x$ of type $k, k=1, \ldots, 10$. This holds for all exogenous variables except for current account, export market share and inverted curve yield where

$$
Z_{q}^{j k}= \begin{cases}1, & \text { if } x^{k} \leq x_{j q}^{k} \\ 0, & \text { otherwise }\end{cases}
$$

Finally, for each optimal quantile, we compute the following two statistics:

$$
\text { Probstress }_{k}^{j}=\frac{T P_{k}^{j}}{T P_{k}^{j}+F P_{k}^{j}}
$$

and

$$
\text { StressCalled }_{k}^{j}=\frac{T P_{k}^{j}}{T P_{k}^{j}+F N_{k}^{j}}
$$

where Probstress ${ }_{k}^{j}$ is the probability that a fiscal stress situation on endogenous variable $j$ occurs given that the explanatory variable $k$ is signaling that it does. Stresscalled ${ }_{k}^{j}$ is the probability that a fiscal stress situation on endogenous variable $j$ is correctly predicted by explanatory variable $k$ when it occurs.

\subsection{Global indexes}

We combine the different explanatory variables to obtain some composite early warning indicators of fiscal vulnerability. We consider three aggregate indices, called Index ${ }^{M I P}$, Index ${ }^{F S}$ and Index ${ }^{O}$, depending upon whether the aggregate index consists of the weighted average of the MIP, FSI or both types of variables. These indices for each endogenous variable $j$ are:

$$
\begin{aligned}
& \text { MIPindex: Index }{ }_{j}^{M I P}=\sum_{k=1}^{n 1} \frac{1}{N S R_{k}^{j}} \hat{Z}^{j k} \\
& \text { FSIindex: Index }{ }_{j}^{F S}=\sum_{k=1}^{n 2} \frac{1}{N S R_{k}^{j}} \hat{Z}^{j k} \\
& \text { Globalindex: } \text { Index }_{j}^{O}=\sum_{k=1}^{n 3} \frac{1}{N S R_{k}^{j}} \hat{Z}^{j k}
\end{aligned}
$$

with

\footnotetext{
13 The TME approach gives a greater weight to misclassifying fiscal vulnerability events (type I and type II false signals) than the NSR approach which gives a greater weight to the fiscal stress episodes that are correctly predicted.
} 


$$
\hat{Z}_{q}^{j k}= \begin{cases}Z_{q}^{j k}, & \text { if } N S R_{k}^{j}<1 \\ 0, & \text { otherwise }\end{cases}
$$

and $n 1=9$ denotes the 9 indicators of MIP, $n 2=7$ denotes the 7 FSI indicators, and $n 3=n 1+n 2$. We replicate the exercise of the preceding sections to see whether the aggregate indexes are early warning indicators of fiscal stress (see Tables 1 and 2).

\section{Data and results based on early warning indicators}

\subsection{Data}

We consider a panel of 8 euro area countries (Austria, Belgium, Finland, France, Germany, Italy, the Netherlands and Spain) over a period from 1998 to 2011. The dataset is restricted to the eight countries for which we have complete information on FSI. The frequency of data is annual. We predict fiscal vulnerability at time $t$, using the information in the explanatory variables at time $t-1$. A detailed description of the data and their sources is given in Appendix A (Table A1).

\subsection{Main results from the early warning indicator models}

\subsubsection{Performance of the indicators in predicting fiscal vulnerability}

For purpose of illustration, and to save space, Table B1 in Appendix B shows the performance of the individual indicators when fiscal stress is measured by sovereign bond spreads. Other tables where fiscal stress is defined by year-on-year interest burden to fiscal revenue ratio, duration, convexity, skewness and kurtosis of bond price are available upon request to the authors. Table B2 shows the best performing individual and aggregate indicators for each fiscal stress variable according to criteria 1 , 2 and 3 (respectively the lowest NSR, the highest Stresscalled and the highest Probstress).

These tables suggest that the composite indexes (combinations of the indicators) provide more information to signal a situation of fiscal vulnerability than do the individual variables. Indeed, the NSR of the aggregate indexes ( $I n d e x_{j}^{M I P}$, Index $x_{j}^{F S}$, and $I n d e x_{j}^{O}$ ) is lower than those of the individual indicators. They always send less false signal, compared to their individual components. Moreover, the probability of correctly predicting a stress event (Probstress) with the aggregate indexes is higher than the probability obtained with the individual variables (see the last column of Table B1). We find that the composite FSI index and the global index predict a higher percentage of "true" fiscal stress episodes (Stresscalled) than when the MIP variables are considered alone as leading indicators of a stress (0.72 and 0.65 against 0.15 ). Then, from the analysis of Table B2, the results suggest that fiscal vulnerability can be caused by different factors, depending on how we measure fiscal stress and on the criteria used to rank the explanatory variables in terms of their predictability power.

When fiscal stress is measured by sovereign bond spreads, the unemployment rate and house price index are the best leading indicators insofar as they have the lowest NSR. Table B2 shows that private sector debt has a good explanatory power when the fiscal stress variable is the year-on-year change of debt burden to fiscal income ratio.

When the variables used to define fiscal vulnerability are bond price duration, convexity, skewness or kurtosis (see Table B2), a forthcoming fiscal stress can be gauged mainly through private sector debt, changes in house price index and export market share. These indicators also have the best predictive power, when considering the third criterion (Probstress). These findings suggest chain reactions. The risk premium on sovereign debt is first conditioned by economic policy variables, specifically the way in which governments succeed in tackling unemployment. Then, the markets' reactions to changes in interest rates are affected by risk factors inherent to the private sector imbalances: firms' and households' over-indebtedness, and external competitiveness as reflected by export market share.

Next consider the second criteria, e.g. the percentage of situation of fiscal vulnerability correctly predicted (Stresscalled) for each endogenous variable. Among the factors signaling a future occurrence of a fiscal stress, many reflect financial imbalances: liquidity risks, as reflected by ted spreads, 
Table 2

Estimated thresholds for the indicators with signal approach

\begin{tabular}{|c|c|c|c|c|c|c|c|c|}
\hline Threshold & With & $\begin{array}{l}\text { Sovereign bond } \\
\text { spread }\end{array}$ & $\begin{array}{l}\text { Yoy debt } \\
\text { service/ } \\
\text { revenue }\end{array}$ & $\begin{array}{l}\text { Bonds price } \\
\text { duration }\end{array}$ & $\begin{array}{l}\text { Bonds price } \\
\text { convexity }\end{array}$ & $\begin{array}{l}\text { Bonds price } \\
\text { skewness }\end{array}$ & $\begin{array}{l}\text { Bonds price } \\
\text { kurtosis }\end{array}$ & $\begin{array}{l}\text { Total } \\
\text { stress }\end{array}$ \\
\hline MIP indicators & European Commission & & & & & & & \\
\hline Current account & $-4 \%$ & 6.50 & -0.51 & 3.70 & -3.57 & 5.33 & 1.94 & 2.83 \\
\hline Unemployment & $10 \%$ & 11.32 & 7.16 & 7.16 & 8.37 & 4.03 & 4.80 & 7.16 \\
\hline Export market share & $-6 \%$ & 6.45 & -17.37 & -10.10 & -6.93 & -13.39 & 6.45 & -17.37 \\
\hline NULC & $9 \%$ & 6.45 & 10.78 & 10.78 & 8.87 & 1.15 & 1.15 & -0.58 \\
\hline Public debt & $60 \%$ & 106.10 & 106.10 & 95.56 & 95.56 & 106.10 & 95.56 & 106.10 \\
\hline REER & $5 \%$ & -5.87 & 2.90 & 6.09 & 6.09 & -5.87 & -0.63 & -5.87 \\
\hline HPI & $6 \%$ & 9.78 & 0.16 & 9.78 & 9.78 & 3.36 & 2.26 & 0.16 \\
\hline Private sector debt & $160 \%$ & 103.40 & 211.00 & 122.10 & 103.40 & 150.60 & 191.00 & 103.40 \\
\hline Private sector debt flow & $15 \%$ & 10.20 & 1.30 & 20.50 & 20.50 & 5.40 & 12.20 & 20.50 \\
\hline MIP index & - & 7.98 & 9.26 & 6.2 & 5.24 & 6.43 & 7.56 & 6.34 \\
\hline FSI indicators & Cardarelli et al. (2009) & & & & & & & \\
\hline Beta & $\geq 1$ & -0.03 & 0.81 & -0.33 & -0.46 & -0.33 & 0.81 & 0.52 \\
\hline Ted spread & $\geq 0.5$ & 0.94 & 0.15 & -0.73 & -0.79 & -0.19 & -0.52 & -0.52 \\
\hline Inverted curve yield & $\leq 0$ & -0.08 & -1.26 & -0.73 & -0.84 & -0.73 & -1.26 & -0.73 \\
\hline Corporate spread & $\geq 0$ & -1.13 & -0.13 & 0.01 & -1.13 & 0.09 & -1.13 & -0.13 \\
\hline Stock return & - & -0.25 & 0.63 & 0.34 & -0.25 & 0.03 & 0.03 & -0.18 \\
\hline Rsq stock return & - & -0.68 & 0.63 & -0.68 & -0.68 & -0.68 & 1.07 & -0.36 \\
\hline Rsq REER change & - & -0.49 & -0.05 & -0.27 & -0.27 & 0.07 & -0.49 & 0.07 \\
\hline FSI index & - & 5.10 & 7 & 4.90 & 4.57 & 3.90 & 2.25 & 3.34 \\
\hline Global index & - & 9.12 & 15.63 & 8.94 & 8.48 & 11.10 & 10.92 & 9.97 \\
\hline
\end{tabular}

Note: REER is the real effective exchange rate. NULC is the nominal unit labor cost. HPI is the real house price index. Rsq stock return is the volatility of stock market returns and Rsq REER change is the volatility of real effective exchange rate. 
stock market volatility, corporate bond spreads. Fiscal vulnerability is thus related to financial imbalances, specifically to pressure in credit markets, sharp changes in stock market volatility.

Turning to the performance of the aggregate indicators in Table B2, the results show that MIP and the global index give the best scores based on criteria 1 and 3 (lowest NSR and highest Probstress) (except for sovereign bond spread and bond price kurtosis). The FSI index has usually the highest percentage of correctly reported situations of fiscal vulnerability (criteria 2).

A look at the thresholds estimated for the different indicators (see Table 2) shows that the markets' view about the financial imbalances leading to fiscal stress situations sometimes differs substantially from the European Commission's (EC's) view. To show this, we report the EC's thresholds for the MIP indicators and our own estimated thresholds. A comparison of the numbers in columns 5, 6, 7, 8 and 9 with the thresholds defined by the EC (column 2) suggests that fiscal stress (as captured by the bond price reactions to changes in the interest rates and by the first two moments of bond price distribution) can arise following "small" macroeconomic imbalances, e.g. (i) a current account deficit below $4 \%$ (interestingly, markets take into account both sides of imbalances, since a surplus above $3.7 \%$ or $5.3 \%$ is also interpreted as a source of fiscal vulnerability for the euro area), (ii) a low unemployment rate (below 10\%), (iii) a private sector debt lower than 160\% of GDP (except for column 8 ).

This suggests differences of perception of a fiscal vulnerability situation, between policymakers and investors in the bond markets. The latter relates a situation of fiscal stress to the conditions for financing debt, in general over short-term horizons. Risk-adverse investors holding government bonds are sensitive to small macro-financial imbalances. The finding of threshold values below those of the European Commission (EC) for the MIP indicators could illustrate that the market price of risk associated with the MIP variables is high (a small imbalance is considered as a big source of risk).

\section{Results based on probit models}

\subsection{The estimated equations}

We consider four specifications of probit models. The first equation is based on the MundlakChamberlain estimator to correct for biases due to the correlation between the effects and the explanatory variables in the random effects model. ${ }^{14}$ Such a correlation is captured by an equation relating the random individual fixed effects to the mean group of the variables. Specifically, the estimated model consists of the following two equations:

$$
\begin{aligned}
\operatorname{Prob}\left(y_{i t}=1 / X_{i t}, Z_{i t}\right) & =\Phi\left(\alpha_{i}+X_{i t}^{\prime} \beta+Z_{i t}^{\prime} \gamma\right) \\
\alpha_{i} & =\alpha+\bar{X}_{i t}^{\prime} \delta+\bar{Z}_{i t}^{\prime} \rho+u_{i}
\end{aligned}
$$

where $\Phi$ is the cumulative density function (CDF) of the standard normal density, $X$ and $Z$ are the vectors of the MIP and FSI variables, and $\beta, \gamma$ are the parameters of interest. $\delta=\rho=0$ produces the standard probit random effect model. Equation (16) is estimated by applying the Buttler-Moffit method and choosing a number of nodes equals to 15 in the Gauss-Hermite polynomial for integration. The standard errors are computed using robust sandwich covariance matrix estimation. We test the null hypothesis that $\delta=\rho=0$ (random effect model) using a joint Wald test.

A natural competitor to the random effect model is the fixed effect model. A simple formulation is based on the latent variable representation:

$$
\begin{aligned}
& y_{i t}^{*}=\alpha_{i} d_{i t}+X_{i t}^{\prime} \beta++Z_{i t}^{\prime} \gamma+\epsilon_{i t} \\
& y_{i t}= \begin{cases}1, & \text { if } y_{i t}^{*}>0 \\
0, & \text { otherwise }\end{cases}
\end{aligned}
$$

\footnotetext{
${ }^{14}$ See Chamberlain (1980) and Mundlak (1978).
} 
where $i=1, \ldots, N$ and $t=1, \ldots, T$. $d_{i t}$ is a dummy variable that takes the value 1 for country $i$ at time $t$ and zero otherwise. To correct for potential bias due to incidental parameter problem, we estimate this model by conditional likelihood estimator and call it conditional fixed effects estimator (CFE).

As a third specification, we consider a model in which some of the exogenous variables are assumed to be endogenous in the sense that they could be correlated with the error term. Formally, the model is defined in terms of a latent variable $y_{i t}^{*}$ and is written as follows:

$$
\begin{aligned}
& y_{i t}^{*}=\omega_{i t}^{1^{\prime}} \mu_{1}+\omega_{i t}^{2^{\prime}} \mu_{2}+\epsilon_{i t}^{1}, \\
& \omega_{i t}^{1}=\omega_{i t}^{2^{\prime}} \lambda_{1}+\omega_{i t}^{3^{\prime}} \lambda_{2}+\epsilon_{i t}^{2} \\
& y_{i t}= \begin{cases}1, & \text { if } y_{i t}^{*}>0 \\
0, & \text { otherwise }\end{cases}
\end{aligned}
$$

where $i=1, \ldots, N$ and $t=1, \ldots, T$. $\omega_{i t}^{1}$ is a vector of endogenous explanatory variables. $\omega_{i t}^{2}$ is a vector of exogenous explanatory variables and $\omega_{i t}^{3}$ is a vector of instrumental variables. $\mu_{1}$ and $\mu_{2}$ are vectors of structural parameters, while $\lambda_{1}$ and $\lambda_{2}$ are reduced-form parameters. The vector $\left(\epsilon_{i t}^{1}, \epsilon_{i t}^{2}\right)$ is assumed to be multivariate normal with variance-covariance matrix

$$
\left(\begin{array}{cc}
1 & \Sigma_{12}^{\prime} \\
\Sigma_{12} & \Sigma_{22}
\end{array}\right)
$$

The model is estimated using Newey's efficient two-step estimator.

Fourthly, we consider a dynamic specification, since the probability of a fiscal stress at time $t$ can depend upon the state observed in the preceding period. We estimate a first-order unobserved effect model:

$$
\operatorname{Prob}\left(y_{i t}=1 / X_{i t}, Z_{i t}, \Omega_{i t}\right)=\Phi\left(\alpha_{i}+X_{i t}^{\prime} \beta+Z_{i t}^{\prime} \gamma+\Omega_{i t}^{\prime} \delta+\rho y_{i t}\right)
$$

where $X_{i t}$ is the vector of MIP variables, $Z_{i t}$ is the vector FSI variables and $\Omega_{i t}$ is the vector of instrumental variables. The main problem with this model is the correlation between the initial value $y_{i 1}$ and $\alpha_{i}$ (initial condition problem). Several estimators have been proposed in the literature. ${ }^{15}$ In this paper, we use the Wooldridge estimator by applying maximum likelihood to the following model:

$$
\operatorname{Prob}\left(y_{i t}=1 / X_{i t}, Z_{i t}, \Omega_{i t}, y_{i 1}\right)=\Phi\left[\left(2 y_{i t}-1\right)\left(\alpha_{0}+X_{i t}^{\prime} \beta+Z_{i t}^{\prime} \gamma+\Omega_{i t}^{\prime} \delta+\rho y_{i t-1}+\eta y_{i 1}+\bar{\Omega}_{i t}^{\prime} \tau+\epsilon_{i t}\right)\right] \quad t=1, \ldots, T .
$$

\subsection{Data}

\subsubsection{Endogenous variable}

Our endogenous variable is a "synthetic" indicator of the 6 fiscal stress variables used in the previous sections. The sovereign bond spread, interest burden, convexity, duration, kurtosis and skewness of price bonds are considered jointly and used to obtain a series of zeros and ones. A 1 defines a regime of fiscal vulnerability during which at least two out of these six variables cross their benchmark value, computed as their mean plus 0.5 times their standard deviation. An alternative approach would consist in defining a fiscal stress episode as a situation in which the majority of our six individual endogenous variables signals a stress. However, doing this leads a vector with very few "1". For instance, with $\lambda=0.5$ we obtain 14 entries with " 1 " over more than 100 observations. This criterion therefore leads a high number of missed stress signals (zeros when " 1 " should be observed). For instance, the indicator does not show the fiscal stress episodes in France and Germany during the years which preceded the reform of Stability and Growth Pact in 2005. With our criterion, we avoid such a caveat.

\footnotetext{
15 See, among others, Dong and Lewbel (2015), Honoré and Kyriazidou (2010), Heckman (1981), and Wooldridge (2000).
} 
Figs. C1-C8 in Appendix C show the historical episodes of fiscal stress as well as the vulnerability episodes signaled by the composite MIP and FSI variables. Interestingly, the aggregate indicator appears to trace out fiscal stress episodes that tracks some historical patterns of fiscal vulnerability in the euro area countries. For purpose of illustration, we begin with the case of Germany. Fig. C5 suggests that this country experienced many fiscal stress episodes from 1999 until 2006. This conforms with the conclusions of previous studies on the historical analysis of German public finances (see, among others, Burret et al., 2013; Palazuelos-Martinez, 2008). The deficit-GDP ratio was -1.5\% in 1999, turning to a positive surplus of $1.3 \%$ in 2000 , and then regularly evolved above the limit allowed by the Stability and Growth Pact. The budget deficit was $-2.8 \%$ in 2001, 3.9\% in 2003, -3.2\% in 2005 and still stayed negative to $-1.7 \%$ in 2006 . These bad performances were closely related to the drop in the economic growth in the early 1990s, followed by severe economic weaknesses from 2001 onward. But Fig. C5 also suggests that fiscal stress could have reflected negative financial shocks factoring into fiscal developments (the FSI variables appear as good leading indicators of fiscal stress). This finding is consistent with the literature on macro-financial linkages in the European economy, which shows that the beginning 2000s were years of heightened financial stress in the European countries, including Germany (see, Matheson, 2012; van Roye, 2011). Firstly, uncertainty about growth prospects resulted into funding stress as manifest in a rise in several spreads and increased volatility of stock prices. Secondly, in a context of large waves of banking and industrial restructing, the investors showed an appetite for private corporate bonds at the expense of sovereign bonds. And thirdly, merging and acquisition transactions made long-term bond with fixed yield less attractive than short-term securities. This has led the countries to borrow at a higher rate than the level at which they could have borrowed otherwise.

Figs. C1-C8 suggest that the German case is part of a broader context of fiscal stress across the euro area countries, especially during the early 2000s. However, there are differences between countries. The Netherlands seems to have been more insulated from fiscal vulnerability, since only three years of fiscal stress are observed corresponding to 2006, 2007 and 2008. In contrast, stressful fiscal episodes were more frequent, as in Germany, in Belgium, France and Italy. In Belgium and Italy, fiscal vulnerability was attributable to MIP imbalances, more than in the other countries. This observation is taken to suggest that in these countries fiscal vulnerability was partly of a macroeconomic nature. In the case of Spain, it seems that the governments were able to avoid fiscal stress as there are only two years in which fiscal vulnerability appears. As is known from the literature, Spain has been capable of sustaining its fiscal situation at the expense of other macro-financial disequilibrium (trade deficits, credit and housing bubbles).

Finally, one might point out that, for all the countries except Finland, the FSI indicators signals fiscal stress from 2007 onward, although this is neither evidenced by the endogenous variable, nor signaled by the MIP variables. Given what is known about the debt crises that eventually occurred after 2011, the FSI variables could be viewed as better leading indicators of forthcoming fiscal vulnerability than the recommended MIP indicators by the EC. Moreover, though Germany has been the least affected by the debt crises, the fact that the FSI also signals a stress for this country could be interpreted as an indirect contagion effect since most of its economic partners were victims of a fiscal stress.

\subsubsection{Exogenous variables and instruments}

We consider two types of regressions. Firstly, we use the MIP indicators as explanatory variables. And, secondly, we add the FSI variables. Our aim is to see whether these additional variables help improve the predictibility of fiscal stress episodes. For the IV estimator and dynamic models, we choose our instruments among the following variables selected according to their degree of correlation with the explanatory variables and to the results of the exogeneity tests for the IV probit models: financial sector balance sheet (liabilities), GDP deflator relative to the rest of 37 industrial countries, average annual hours worked per person employed, output-gap, current tax burden (total economy), terms of trade (goods and services), total factor productivity (total economy), marginal efficiency of capital (total economy), net primary income from the rest of the world, net capital transactions with the rest of the world, bank non-performing loans to total gross loans, SP global equity index.

More details about the sources of these variables are provided in Appendix A (Table A2). We prefer these macroeconomic and financial variables, which are linked to our macro-financial explanatory variables, rather than considering lags of the explanatory variables as is often done in the literature. 


\subsection{Regression results}

We present the average partial effects estimated from the four models in Tables 3 and 4. For the Mundlak-Chamberlain estimator, we also report the Wald test of the null hypothesis of no correlation between the individual effects and the explanatory variables. We also show the Wald test of exogeneity of the instruments for the IV probit model. The null hypothesis cannot be rejected as the estimated significance level is higher than $5 \%$.

\subsubsection{Comparing the models}

If we consider the performance of the models in terms of predictability as a goodness-of-fit measure, we see that the dynamic model is outperformed by the static models (Mundlak-Chamberlain, Conditional FE logit and IV probit). Indeed, the probability of correctly predicting a situation of fiscal stress, or a regime of no stress, is lower for this model compared with the other three alternative models. In order to assess whether adding the FSI variables delivers a significant improvement to MIP indicators, we conduct a Likelihood Ratio test. We obtain, for all specifications, p-values (significance levels) lower than 0.05 . This indicates that the models with all MIP and FSI predictors fit significantly better than those with only the MIP indicators.

The estimates of the dynamic model suggest that a fiscal stress event today does not affect the occurrence of a future fiscal stress. Indeed, the coefficient of the lagged endogenous variable is nonsignificant. There is no path-dependence, but only a sensitivity to initial conditions as shown by the significant estimates of the coefficient of initial endogenous variable. This suggests that better information about fiscal stress is provided by a static model with unobserved heterogeneity among countries (idiosyncratic initial fiscal stress). We therefore focus on the first three models. Comparing these models, the results on the predictive accuracy of fiscal stress episodes suggest that a specification with FSI variables always outperforms a specification with the MIP indicators only (see the percentage of stress episodes correctly predicted). For instance, a IV probit model with the MIP variables accounts for 70\% of the observed fiscal stress episodes. Adding the FSI variables improves this statistic up to $80 \%$.

Since the coefficients of these variables are statistically significant in Table 4, leaving them out in the regressions of Table 3 leads to a problem of omitted variables. Indeed, since the FSI variables are significant variables to predict fiscal stress, their omission would lead to over- or underestimating the effects of the MIP variables. This omitted-variable bias occurs because the MIP and FSI variables are correlated (see the matrix of correlation in Table B3 in Appendix B). Such correlations illustrate the hypothesis of global imbalances affecting public finances. In this case, estimating a probit or logit model without FSI variables induces a correlation between the MIP variables and the error term, unless we use instrumental variables. In this regard, the IV probit estimator in Table 3 is the most reliable. However, given the fact that the models with FSI give the best predictions of both stress and no stress episodes, our comments will focus on the results contained in Table 4. As suggested by Wooldridge (2000), leading competitors to correlated random effect models are fixed effect methods. We therefore compare the Mundlak-Chamberlain estimates with conditional fixed effect estimators. We consider conditional estimators to deal with the usual problem of incidental parameters in fixed effect models. Finally, as some of our regressors may be endogenous, we further consider an instrumental variable models. The three models are presented for purpose of robustness, specifically to check that the sign of the coefficient does not change with different estimators.

\subsubsection{Impact of the MIP and FSI variables on fiscal stress}

We start by examining the influence of MIP variables. The results provide some support for a lower likelihood of fiscal stress when the current account surplus improves (negative coefficients), in case of a higher export market share (negative coefficients), when the ratio of public debt diminishes (positive coefficient), or in a context of decreasing unemployment rate (positive coefficient). An increase in the house price leads to higher fiscal vulnerability (positive coefficient). This is in support of the view that an upward trend in house markets poses risks to future financial stability and consequently to public budget in case of government intervention to safeguard the housing sector. A depreciation of the real effective exchange rate (an increase in REER) implies a higher fiscal vulnerability as evidenced by the positive coefficients in Table 4. The reasons are twofold. Firstly, it creates fears of higher inflation and thus drives up the inflation risk-premium as a compensation for bearing inflation risk. 
Table 3

Probit models with the MIP indicators as explanatory variables.

\begin{tabular}{|c|c|c|c|c|c|c|c|c|}
\hline & \multicolumn{2}{|c|}{ RE probit Mundlak-Chamberlain } & \multicolumn{2}{|c|}{ Conditional FE logit } & \multicolumn{2}{|c|}{ Two-step IV probit } & \multicolumn{2}{|c|}{$\begin{array}{l}\text { Dynamic probit } \\
\text { for panel data }\end{array}$} \\
\hline & Coeff & Std & Coeff & Std & Coeff & Std & Coeff & Std \\
\hline Current account & $-2.56^{* * *}$ & 0.14 & -1.13 & 1.26 & $-0.76^{* * *}$ & 0.15 & 0.33 & 0.69 \\
\hline Unemployment & -0.41 & 0.91 & -0.20 & 0.40 & -0.13 & 0.39 & $-1.64^{* * *}$ & 0.01 \\
\hline Export market share & $7.76^{* * *}$ & 0.74 & $1.97^{* *}$ & 1.13 & $2.37^{* * *}$ & 0.79 & $-5.23^{* * *}$ & 0.85 \\
\hline NULC & $6.21^{* * *}$ & 0.78 & $5.86^{* * *}$ & 2.65 & $6.71^{* * * *}$ & 0.88 & $-2.14^{* * *}$ & 0.32 \\
\hline Public debt & $-10.36^{* * *}$ & 0.15 & $-11.28^{* * *}$ & 1.76 & $-11.69^{* * *}$ & 0.06 & $-3.25^{*}$ & 1.85 \\
\hline REER & $-0.36^{*}$ & 0.26 & $0.16^{*}$ & 0.11 & 0.22 & 0.26 & $-1.88^{* * *}$ & 0.48 \\
\hline HPI & $2.96^{* * *}$ & 0.79 & $2.53^{* * *}$ & 0.57 & $2.48^{* * *}$ & 0.01 & $-1.85^{* * *}$ & 0.41 \\
\hline$y_{i 1}$ & - & - & - & - & - & - & $-6.79^{* * *}$ & 0.77 \\
\hline Lagged endogenous & - & - & - & - & - & - & -0.05 & 0.25 \\
\hline$\% \operatorname{correct}(\mathrm{y}=0)$ & 89 & & 87 & & 89 & & 81 & \\
\hline$\% \operatorname{correct}(\mathrm{y}=1)$ & 75 & & 80 & & 70 & & 61 & \\
\hline & \multicolumn{4}{|c|}{ Wald test: $\chi^{2}(7)=294.256$ or $P-$ value $=0.00$} & \multicolumn{2}{|c|}{$\begin{array}{l}\text { Wald test of exogeneity: } \chi^{2}(7)=4.86 \\
P-\text { value }=0.67\end{array}$} & & \\
\hline
\end{tabular}

Note: The coefficients reported are partial effects. ******: Statistically significant at $10 \%, 5 \%$ and $1 \%$ level of significance. NULC, nominal unit labor cost; REER, real effective exchange rate; HPI, real house price index. Wald test for RE probit: the null hypothesis is $\delta=\rho=0$ (random effect model) in Equation (16) and p-value is the significance level of the test. Wald test for IV probit: the null hypothesis is the exogeneity of the instruments and p-value is the significance level of the test. 
Table 4

Probit models with the MIP and FSI indicators as explanatory variables.

\begin{tabular}{|c|c|c|c|c|c|c|c|c|}
\hline & \multicolumn{2}{|c|}{$\begin{array}{l}\text { RE probit } \\
\text { Mundlak-Chamberlain }\end{array}$} & \multicolumn{2}{|c|}{ Conditionnal FE logit } & \multicolumn{2}{|c|}{ Two-step IV probit } & \multicolumn{2}{|c|}{$\begin{array}{l}\text { Dynamic probit } \\
\text { for panel data }\end{array}$} \\
\hline & Coeff & Std & Coeff & Std & Coeff & Std & Coeff & Std \\
\hline Current account & $-4.45^{* * *}$ & 0.11 & $-2.34^{* * *}$ & 0.85 & $-2.44^{* * *}$ & 0.11 & -0.18 & 1.08 \\
\hline Unemployment & -0.14 & 0.47 & $-0.54^{*}$ & 0.35 & $-0.57^{* * *}$ & 0.23 & $-1.16^{* * *}$ & 0.01 \\
\hline Export market share & $4.58^{* * *}$ & 0.42 & $1.21^{* * *}$ & 0.50 & $1.20^{* * *}$ & 0.61 & $-9.81^{* * *}$ & 0.9 \\
\hline NULC & $1.15^{* * *}$ & 0.41 & 2.61 & 2.75 & $3.31^{* * * *}$ & 0.69 & $5.22 * * *$ & 0.09 \\
\hline Public debt & $-4.88^{* * * *}$ & 0.11 & $-6.90^{* * *}$ & 2.79 & $-7.60^{* * * *}$ & 0.05 & $-13.74^{* * *}$ & 0.80 \\
\hline REER & $1.08^{* * *}$ & 0.14 & $0.56^{* * *}$ & 0.13 & $0.54^{* * *}$ & 0.19 & $-1.08^{* * * *}$ & 0.26 \\
\hline HPI & $2.04^{* * *}$ & 0.01 & $1.99^{* * * *}$ & 0.40 & $2.08^{* * * *}$ & 0.02 & $-1.02^{* * *}$ & 0.14 \\
\hline Beta & $-0.11^{* * *}$ & 0.02 & $-0.15^{* * *}$ & 0.05 & $-0.14^{* * *}$ & 0.03 & 0.02 & 0.04 \\
\hline Ted spread & $-0.29^{* * *}$ & 0.02 & $-0.14^{*}$ & 0.10 & $-0.15^{* * *}$ & 0.02 & $-0.21^{* * *}$ & 0.03 \\
\hline Inverted curve yield & $0.11^{* * *}$ & 0.01 & $0.14^{* * * *}$ & 0.03 & $0.14^{* * *}$ & 0.01 & $-0.10^{* * *}$ & 0.03 \\
\hline Corporate spread & $0.24^{* * *}$ & 0.03 & $0.16^{* * *}$ & 0.04 & $0.15^{* * *}$ & 0.04 & -0.07 & 0.06 \\
\hline Stock return & $-0.45^{* * *}$ & 0.01 & $-0.53^{* * *}$ & 0.22 & $-0.49^{* * *}$ & 0.01 & $0.56^{* * *}$ & 0.02 \\
\hline Rsq stock return & -0.05 & 1.20 & -0.03 & 0.02 & -0.01 & 0.01 & $0.17^{* * * *}$ & 0.01 \\
\hline$y_{i 1}$ & - & - & - & - & - & - & $-6.27^{* * *}$ & 0.76 \\
\hline Lagged endogenous & - & - & - & - & - & - & -0.03 & 0.11 \\
\hline$\%$ correct $(y=0)$ & 92 & & 87 & & 90 & & 86 & \\
\hline \multirow[t]{6}{*}{$\% \operatorname{correct}(\mathrm{y}=1)$} & 88 & & 91 & & 80 & & 74 & \\
\hline & \multicolumn{2}{|c|}{$\begin{array}{l}\text { Wald test: } \\
\chi^{2}(7)=358.15\end{array}$} & & & \multicolumn{2}{|c|}{$\begin{array}{l}\text { Wald test of exogeneity: } \\
\chi^{2}(13)=9.62\end{array}$} & & \\
\hline & \multicolumn{2}{|c|}{$P-$ value $=0.00$} & & & \multicolumn{2}{|c|}{$P-$ value $=0.724$} & & \\
\hline & \multirow{2}{*}{\multicolumn{2}{|c|}{$\begin{array}{l}\text { LR test: } \\
\chi^{2}(12)=32.66\end{array}$}} & \multirow{3}{*}{\multicolumn{2}{|c|}{$\begin{array}{l}\text { LR test: } \\
\chi^{2}(6)=26.84 \\
P-\text { value }=0.00\end{array}$}} & \multirow{2}{*}{\multicolumn{2}{|c|}{$\begin{array}{l}\text { LR test: } \\
\chi^{2}(6)=27.79\end{array}$}} & \multirow{3}{*}{\multicolumn{2}{|c|}{$\begin{array}{l}\text { LR test: } \\
\chi^{2}(6)=15.13 \\
P-\text { value }=0.02\end{array}$}} \\
\hline & & & & & & & & \\
\hline & \multicolumn{2}{|c|}{$P-$ value $=0.00$} & & & \multicolumn{2}{|c|}{$P-$ value $=0.00$} & & \\
\hline
\end{tabular}

Note: The coefficients reported are partial effects. ${ }^{* * * *}$ : Statistically significant at $10 \%, 1 \%$ level of significance. Beta: banking sector beta. NULC, nominal unit labor cost; REER, real effective exchange rate; HPI, real house price index. Wald test for RE probit: the null hypothesis is $\delta=\rho=0$ (random effect model) in Equation (16) and p-value is the significance level of the test. Wald test for IV probit: the null hypothesis is the exogeneity of the instruments and p-value is the significance level of the test. Likelihood ratio (LR) test: the null hypothesis is the unrestricted model (with MIP + FSI indicators) fitting the data significantly better than the more restrictive model (with only MIP indicators). This statistic is distributed chisquared, with degrees of freedom equal to the number of parameters that are constrained. 
Secondly, increases in inflation following a real depreciation is associated with expectations of higher nominal interest rates (because inflation is the main target of the European Central Banks policy). If monetary policy obeys the Taylor principle, then real interest rates are expected to increase. The adverse effects on economic growth may result into higher fiscal deficits (through lower fiscal revenues), which in turn can lead to rising costs of borrowing in sovereign bond markets.

Depending on which channel dominates, an increase in nominal unit labor costs leads to higher or lower fiscal vulnerability. A first channel relates nominal wages to inflation (through the wageprice loop) and results into a higher fiscal risk through higher interest rate premium. A second channel works through the current account balance. It is of relevance to explain higher imbalances of current account positions due to the deterioration of competitiveness, leading to higher interest rates to avoid capital outflows. Both these channels should ultimately lead to a positive sign of the coefficient related to unit labor cost since they increase fiscal vulnerability. This is not the case here. There is a third channel whose impact on fiscal stress plays in the opposite direction. This corresponds to the so-called catchup channel. From 1999 to 2011, higher wages in some countries of the euro area reflected a catch-up dynamics in the sense that their growth rates allowed per-capita output in the peripheral euro area countries to catch-up with those of the other countries. Increases in nominal unit labor costs therefore accompanied higher growth rates, which fueled investors' sentiment that the economic and fiscal situation in the countries were sound, thereby implying a reduced fiscal stress. The negative sign of the unit labor cost coefficients in our regressions suggests that this third channel could have been at play in the euro area.

We now turn to the explanatory power of those variables capturing vulnerabilities in the financial sector (FSI variables). The ted spread is defined as the difference between the 3-month Libor rate and government short-term rate. A decrease in the latter relative to the Libor rate reflects a lower perceived risk of default associated with short-term government bond. This makes the refinancing of shortterm debt less costly and therefore reduces fiscal vulnerability. Thus, the estimated coefficient of this variable enters the regressions with a negative sign. The inverted term spread (short-term minus longterm interest rates) captures markets sentiment about the long-term outlook. An increase is associated with a signal on expectations of pending recessions with lower long-term returns on sovereign bonds. One would expect larger inverted term spread to rise fiscal vulnerability, since an economic depression involves a decrease in fiscal revenues, thereby implying that the sovereign debt appears more risky than before. The finding of a positive sign of the coefficient of this variable in Table 4 accords with this explanation.

A larger coefficient of the beta in the banking sector reflects rising risk of investing in the banking sector (either because share prices are volatile or the cost of equity increases). This makes banks less investible, and investors may increase the portion of their portfolio in risk-free assets (for instance in sovereign bonds). In this case, we expect lower fiscal stress and therefore a negative sign of the beta coefficient as is evidenced in our regressions. The corporate spread (defined as corporate bond yield minus government long-term yield) is taken as a proxy of perceived international financial risk, as is usually done in the empirical literature on the determinants of sovereign bond spreads (see, for instance, Manganelli and Wolswijk, 2009). The positive sign of the estimated coefficients accords with the usual finding in the empirical literature that the international risk factor is an important determinant of bond yields and prominent in the countries with high debt levels, as was already the case in the euro area before the 2010 debt crises (see, among many others, Afonso et al., 2015). Finally, a decline in equity market returns raises fiscal vulnerability (as suggested by the negative sign of the coefficient of this variable), while exposure to tail risk (captured here by the squared returns) has no significant impact on fiscal stress. The reason why a decline in equity returns can result into a higher likelihood of fiscal stress is simply that governments have both explicit and implicit equity ownerships. Explicit ownership means that investing funds into risky corporate equity is part of governments' social security management policy to sustain benefits for the payment of future social security retirement benefits, health or unemployment benefits. Implicit ownership means that governments have position in the equity markets through their claim to future tax revenues. A decrease in asset prices can therefore negatively affect the present value of governments' revenues, thereby implying that the financing of public spending will be supplemented by other resources than taxes, in particular by a higher public debt. In this case, fiscal positions may appear to be less sustainable. 


\section{Conclusion}

The goal of this paper was to investigate the macro-financial imbalances that exposed the Euro area countries to fiscal stress before the outbreak of the debt crises in Europe. This issue was ignited in the academic and policy circles in the wake of the debt crises. We shed some further light on this debate, but from a different perspective. Our analysis applies to normal times, with data covering the years before the recent debt crises. Unlike previous studies, we adopt a "market-based view." We therefore investigate the determinants of fiscal stress/vulnerability understood as changes in the sovereign credit pricing by investors.

Our results indicate that financial stress substantially improves the predictibility of fiscal vulnerability. MIP indicators alone should not be considered as leading indicators of changes in the perception of sovereign bond pricing by market participants. Though the focus up until now has been on fiscal sustainability from a macroeconomic viewpoint, it may also be helpful to monitor the risk inherent to public finances by using market indicators. Our empirical exercise suggests looking at variables such as the exposure to tail risk, investors' perceived risk of default associated with short-term bonds, investors' trade-off between corporate and sovereign bonds, the return of equity indexes relative to bond prices. This paper thus suggests the construction of databases and indicators, in the euro area, that could come as additional variables to the MIP indicators. This is done in order to not only go beyond the issues of fiscal sustainability in the medium-term, but also to have a more careful look at fiscal vulnerability stress as perceived by the holders of sovereign debts. This could help open the "black box" of the grade agencies since their upgrades and downgrades are not necessarily indisputable.

This paper could be extended in at least two directions. First, the econometric framework could be extended to explore other aspects of the links between market-based variables of short-term fiscal vulnerability and their forewarning indicators. For instance, time-varying and non-linear models would help detect structural instability in the relationships between the endogenous and explanatory variables. Secondly, other measures of financial distress could be considered, for instance those involving the investors' reaction to policy communications and initiatives. In this respect, an interesting study could consist in testing the approach proposed by Ait-Sahalia et al. (2012) by extending the period to the years before the European debt crises.

\section{Appendix A. Description of the variables}

Table A1

MIP and FSI variables.

\begin{tabular}{|c|c|c|}
\hline Name of the variables & Indicators & Sources \\
\hline Current account & CA \% GDP & WEO \\
\hline Nominal unit labor cost of labor & $\begin{array}{l}\text { NULC: ratio of compensation per employee to real GDP per } \\
\text { person employed (Eur: } 2005=100 \text { ) }\end{array}$ & AMECO \\
\hline Export market share & $\%$ share of exports of goods and services over world exports & OECD \\
\hline Real effective exchange rate & $\begin{array}{l}\text { Performance relative to the rest of the former EU-15 (double } \\
\text { export weights) }\end{array}$ & OECD \\
\hline Private sector debt & $\%$ of GDP & Eurostat \\
\hline Private sector credit flow & $\%$ of GDP & Eurostat \\
\hline Public debt & $\%$ of GDP & $\begin{array}{l}\text { Fiscal monitor and } \\
\text { IMF (2010) }\end{array}$ \\
\hline House price index & HPI $(2010=100)$ & $\mathrm{ECB}$ \\
\hline Residential property prices & All dwellings, Pure price, Q-all, NSA & $\mathrm{ECB}$ \\
\hline Unemployment rate & $\%$ of total labor force & WEO \\
\hline Bond yields & 10 -year bond yield & Datastream \\
\hline Beta of banking sector & 12-month rolling beta & IMF \\
\hline Ted spreads & $\begin{array}{l}\text { 3-month LIBOR or commercial paper rate minus government } \\
\text { short-term rate }\end{array}$ & IMF \\
\hline Equity market index & Annualized monthly stock returns & IMF \\
\hline Volatility of equity prices & Annualized 6-months rolling squared returns & IMF \\
\hline Foreign exchange volatility & $\begin{array}{l}\text { Annualized 6-months rolling squared change in the exchange } \\
\text { rate }\end{array}$ & IMF \\
\hline Inverted yield curve & Inverted term spread & IMF \\
\hline Corporate bond spread & Corporate bond yield & IMF \\
\hline
\end{tabular}


Table A2

Instrumental variables.

\begin{tabular}{|c|c|c|}
\hline Name of the variables & Indicators & Sources \\
\hline \multirow{3}{*}{$\begin{array}{l}\text { Price deflator (PDGDP) } \\
\text { PriralN) }\end{array}$} & Liabilities of the overall financial sector, unconsolidated - annual data & OCDE \\
\hline & Price deflator gross domestic product: & AMECO \\
\hline & $\begin{array}{l}\text { Performance relative to the rest of } 37 \text { industrial countries: double export } \\
\text { weights (National currency: } 2010=100 \text { ) }\end{array}$ & \\
\hline Average hours worked (AAHWP) & Average annual hours worked per person employed & AMECO \\
\hline Output gap & $\begin{array}{l}\text { Gap between actual and potential gross domestic product at } 2010 \\
\text { reference levels (Percentage of potential gross domestic product at } \\
\text { constant prices) }\end{array}$ & AMECO \\
\hline Current tax burden (CTB) & $\begin{array}{l}\text { Current tax burden: total economy: } \\
\text { - ESA } 2010 \text { Mrd EURO-BEF }\end{array}$ & AMECO \\
\hline Terms of trade (TTGS) & Terms of trade goods and services (National accounts) $(2010=100)$ & AMECO \\
\hline Taxes (TIPC) & Taxes on income, profits and capital gains (\% of total taxes) & AMECO \\
\hline TFP & Total factor productivity: total economy $(2010=100)$ & AMECO \\
\hline Marginal efficiency of capital (MEC) & $\begin{array}{l}\text { Marginal efficiency of capital: total economy (Change in GDP at constant } \\
\text { market prices of year T per unit of gross fixed capital formation at constant } \\
\text { prices of year T-.5.) }\end{array}$ & AMECO \\
\hline Primary income (NPIRW) & $\begin{array}{l}\text { Net primary income from the rest of the world (National accounts) Mrd } \\
\text { EURO-BEF }\end{array}$ & AMECO \\
\hline Capital transactions (NCTRW) & $\begin{array}{l}\text { Net capital transactions with the rest of the world (National accounts) Mrd } \\
\text { EURO-BEF }\end{array}$ & AMECO \\
\hline $\begin{array}{l}\text { Bank non-performing } \\
\text { loans (BNPLTGL) }\end{array}$ & $\begin{array}{l}\text { Bank non-performing loans to total } \\
\text { gross loans }\end{array}$ & WEO \\
\hline SP Global Equity Indices (SPGEI) & S\&P Global Equity Index & WEO \\
\hline Private debt (HNPISHS) & $\begin{array}{l}\text { Households and NPISHs - All sectors } \\
\text { - Market value - Percentage of GDP } \\
\text { - Adjusted for breaks }\end{array}$ & WEO \\
\hline
\end{tabular}

\section{Appendix B. Early warning indicators results}

\section{Table B1}

Performance of the indicators. Endogenous variable: Sovereign bond spreads.

\begin{tabular}{|c|c|c|c|c|c|c|c|}
\hline \multirow[t]{2}{*}{ Advance indicator } & \multicolumn{7}{|c|}{ Threshold $=$ Mean $+0,5 \times$ standard deviation } \\
\hline & $\begin{array}{l}\text { Threshold } \\
\text { quantile }\end{array}$ & $\begin{array}{l}\mathrm{FS}= \\
\mathrm{TP}+\mathrm{FN}\end{array}$ & $\begin{array}{l}\mathrm{Nfs}= \\
\mathrm{FP}+\mathrm{TN}\end{array}$ & $\begin{array}{l}\text { Number of } \\
\text { fiscal stress } \\
\text { called (TP) }\end{array}$ & $\begin{array}{l}\text { Noise to signal } \\
\text { ratio }=((\mathrm{FP} / \mathrm{Nfs})) / \\
((\mathrm{TP} / \mathrm{FS}))\end{array}$ & $\begin{array}{l}\% \text { of Fiscal stress } \\
\text { correctly called = } \\
\mathrm{TP} /(\mathrm{TP}+\mathrm{FN})\end{array}$ & $\begin{array}{l}\mathrm{P}(\text { fiscal stress } / \\
\text { signal }= \\
\mathrm{TP} /(\mathrm{TP}+\mathrm{FP})\end{array}$ \\
\hline \multicolumn{8}{|l|}{ MIP indicators } \\
\hline Current account & Q9( $\leq)$ & 32 & 72 & 30 & 0.93 & 0.94 & 0.32 \\
\hline Unemployment & Q9 & 32 & 72 & 6 & 0.37 & 0.19 & 0.54 \\
\hline Export market Share & Q9( $\leq)$ & 32 & 72 & 24 & 1.28 & 0.75 & 0.26 \\
\hline NULLC & Q1 & 32 & 72 & 24 & 1.29 & 0.75 & 0.25 \\
\hline Public debt & Q9 & 32 & 72 & 4 & 0.77 & 0.12 & 0.36 \\
\hline REER & Q1 & 32 & 72 & 27 & 1.10 & 0.84 & 0.29 \\
\hline HPI & Q9 & 32 & 72 & 6 & 0.37 & 0.19 & 0.54 \\
\hline Private sector debt & Q1 & 32 & 72 & 26 & 1.16 & 0.81 & 0.28 \\
\hline Private sector debt flow & Q6 & 32 & 72 & 20 & 0.49 & 0.62 & 0.48 \\
\hline $\begin{array}{l}\text { MIP index } \\
\text { FSI indicators }\end{array}$ & Q9 & 32 & 72 & 5 & 0.18 & 0.16 & 0.71 \\
\hline Beta & Q5 & 32 & 72 & 20 & 0.71 & 0.62 & 0.38 \\
\hline Ted spread & Q2 & 32 & 72 & 27 & 0.94 & 0.84 & 0.32 \\
\hline Inverted curve yield & Q6( $(\leq)$ & 32 & 72 & 25 & 0.66 & 0.78 & 0.40 \\
\hline Corporate spread & Q1 & 32 & 72 & 28 & 1.05 & 0.87 & 0.3 \\
\hline Stock return & Q2 & 32 & 72 & 20 & 1.42 & 0.62 & 0.29 \\
\hline Rsq stock return & Q1 & 32 & 72 & 26 & 1.16 & 0.81 & 0.28 \\
\hline Rsq REER change & Q1 & 32 & 72 & 31 & 0.90 & 0.97 & 0.33 \\
\hline FSI index & Q8 & 32 & 72 & 23 & 0 & 0.72 & 1 \\
\hline Global index & Q8 & 32 & 72 & 21 & 0.06 & 0.66 & 0.87 \\
\hline
\end{tabular}

Note: Column 1 reports the name of the indicators and of the aggregate indexes. Column 2 shows the quantiles corresponding to the minimum noise-to-signal ratio (NSR) for each indicator. ( $\leq$ ) specifies that this is a lower bound quantile. Column 3 reports the total number of fiscal stress episodes recorded in the data (FS). Column 4 reports the number of no-fiscal stress recorded in the data (Nfs). Column 5 reports the number of fiscal stress episodes that indeed occur (TP). Column 6 reports the minimum NSR. Column 7 shows the percentage of fiscal stress episodes correctly predicted (the variable called Stresscalled in the main text). Column 8 contains the probability that a fiscal stress situation occurs given that the explanatory variable is signaling that it does (the variable called Probstress in the main text). MIP, FSI and Global indexes refer to the composite indicators when one considers the MIP, FSI, and both MPI and FSI variables together. 
Table B2

Best performing individual and aggregate indicators with $\lambda=0.5$.

\begin{tabular}{|c|c|c|c|}
\hline Endogenous variables & 1st Criterion: lowest NSR & $\begin{array}{l}\text { 2nd Criterion: highest } \\
\text { Stresscalled }\end{array}$ & $\begin{array}{l}\text { 3rd Criterion: highest } \\
\text { Probstress }\end{array}$ \\
\hline & \multicolumn{3}{|c|}{ Individual exogenous indicators } \\
\hline Bonds spread & $\begin{array}{l}\text { Unemployment rate, house } \\
\text { price index }\end{array}$ & NEER volatility & $\begin{array}{l}\text { Unemployment rate, house } \\
\text { price index }\end{array}$ \\
\hline Interest burden/fiscal income & Private sector debt & Private sector debt flow & Private sector debt \\
\hline Bond price duration & Export market share & $\begin{array}{l}\text { Current account, } \\
\text { unemployment rate, stock } \\
\text { market volatility }\end{array}$ & Export market share \\
\hline Bond price convexity & $\begin{array}{l}\text { House price index, private } \\
\text { sector }\end{array}$ & Ted spread & $\begin{array}{l}\text { House price index, private } \\
\text { sector debt flow }\end{array}$ \\
\hline Bond price skewness & Export market share & Stock market volatility & Export market share \\
\hline Bond price kurtosis & Private sector debt flow & Corporate spread & Private sector debt flow \\
\hline \multirow{2}{*}{ Total stress } & Public debt & Private sector debt & Public debt \\
\hline & \multicolumn{3}{|c|}{ Aggregate exogenous indicators } \\
\hline Bonds spread & FSI index & FSI index & FSI index \\
\hline Interest burden & MIP index & MIP index & MIP index \\
\hline fiscal income & MIP index & MIP index & MIP index \\
\hline Bond price duration & Global index & Global index & Global index \\
\hline Bond price convexity & MIP index & Global index & MIP index \\
\hline Bond price skewness & MIP index & FSI index & Global index \\
\hline Bond price kurtosis & Global index & FSI index & Global index \\
\hline Total stress & MIP index & FSI index & MIP index \\
\hline
\end{tabular}

Table B3

Correlation matrix between the MIP and FSI variables.

\begin{tabular}{lrrrrrrr}
\hline & Beta & Ted spread & $\begin{array}{l}\text { Corporate } \\
\text { spread }\end{array}$ & $\begin{array}{l}\text { Inverted } \\
\text { curve yield }\end{array}$ & \multicolumn{1}{c}{$\begin{array}{l}\text { Stock } \\
\text { return }\end{array}$} & $\begin{array}{l}\text { Rsq stock } \\
\text { return }\end{array}$ & $\begin{array}{l}\text { Rsq REER } \\
\text { change }\end{array}$ \\
\hline Current account & 0.141 & -0.004 & 0.076 & 0.133 & -0.036 & 0.306 & 0.027 \\
Export market share & -0.327 & 0.014 & 0.028 & 0.326 & -0.247 & -0.299 & 0.069 \\
Unemployment & 0.286 & -0.234 & -0.171 & -0.314 & 0.037 & 0.252 & -0.453 \\
REER & 0.125 & 0.041 & -0.063 & -0.152 & 0.154 & 0.105 & 0.035 \\
NULC & 0.335 & -0.103 & -0.117 & -0.361 & 0.201 & 0.366 & -0.184 \\
Public debt & 0.418 & -0.040 & -0.049 & -0.464 & 0.068 & 0.306 & -0.335 \\
HPI & -0.099 & -0.304 & -0.372 & -0.003 & -0.025 & -0.130 & -0.424 \\
\hline
\end{tabular}


Appendix C. Stress episodes and variables signaling a forthcoming situation of fiscal vulnerability
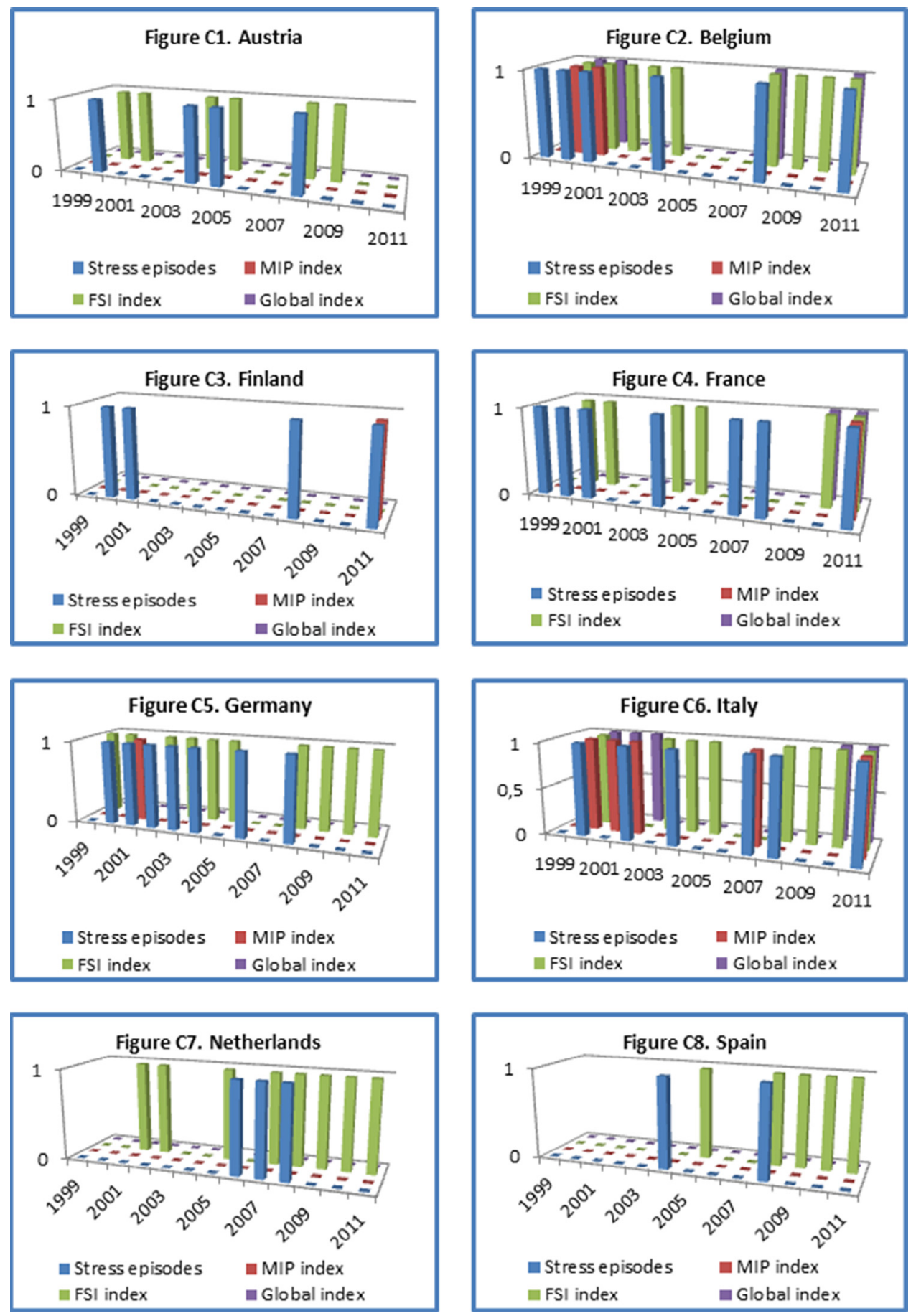


\section{References}

Afonso, A., Nunes, A.S., 2015. Economic forecasts and sovereign yields. Econ. Model. 44, 319-326.

Afonso, A., Arghyrou, M.G., Kontonikas, A., 2012. The determinants of sovereign bond yield spreads in the EMU. SIRE Discussion Papers 2012-88, Scottish Institute for Research in Economics.

Afonso, A., Arghyrou, M.G., Bagdatoglou, G., Kontonikas, A., 2015. On the time-varying relationship between EMU sovereign spreads and their determinants. Econ. Model. 44, 363-371.

Ait-Sahalia, Y., Andritzky, J., Jobst, A., Nowak, S., Tamirisa, N., 2012. Market response to policy initiatives during the global financial crisis. J. Int. Econ. 87, 162-177.

Aizenman, J., Hutchison, M., Jinjarak, Y., 2013. What is the risk of European sovereign debt defaults? Fiscal space, CDS spreads and market pricing of risk. J. Int. Money. Finance 34, 37-59.

Andritzky, J.R., 2012. Government bonds and their investors: what are the facts and do they matter? IMF Working Papers 12/158, International Monetary Fund.

Arslanalp, S., Poghosyan, T., 2014. Foreign Investor flows and sovereign bond yields in advanced economies. IMF Working Papers 14/27, International Monetary Fund.

Balakrishnan, R., Danninger, S., Elekdag, S., Tytell, I., 2011. The transmission of financial stress from advanced to emerging economies. Emerg. Mark. Finance Trade 47, 40-68.

Barr, D.G., Priestley, R., 2004. Expected returns, risk and the integration of international bond markets. J. Int. Money. Finance 23, 71-97.

Beirne, J., Fratzscher, M., 2013. The pricing of sovereign risk and contagion during the European sovereign debt crisis. J. Int. Money. Finance 34, 60-82.

Bernoth, K., Von Hagen, J., Schuknecht, L., 2012. Sovereign risk premiums in the European government bond market. J. Int. Money. Finance 31, 975-995.

Berti, K., Salto, M., Lequien, M., 2012. An early-detection index of fiscal stress for EU countries. European Economy - Economic Papers 475, Directorate General Economic and Financial Affairs (DG ECFIN), European Commission.

Borgy, V., Bouthevillain, C., Dufrénot, G., 2014. Managing the fragility of the Eurozone by Paul De Grauwe. Int. J. Finance Econ. 19, 3-11.

Burret, H., Fed, L., Koehler, E., 2013. Sustainability of public debt in Germany. Historical considerations and time series evidence. J. Econ. Stat. 233, 291-335.

Cardarelli, R., Elekdag, S., Lall, S., 2009. Financial stress, downturns, and recoveries. IMF Working Papers 09/100, International Monetary Fund.

Chamberlain, G., 1980. Analysis of covariance with qualitative data. Rev. Econ. Stud. 47, 225-238.

De Grauwe, P., Ji, Y., 2013. Self-fulfilling crises in the Eurozone: an empirical test. J. Int. Money. Finance 34, 15-36.

De Santis, R.A., 2014. The euro area sovereign debt crisis: identifying flight-to-liquidity and the spillover mechanisms. J. Empir. Financ. 26, 150-170.

Dobrescu, G., Petrova, I., Belhocine, N., Baldacci, E., 2011. Assessing fiscal stress. IMF Working Papers 11/100, International Monetary Fund.

Dong, Y., Lewbel, A., 2015. A simple estimator for binary choice models with endogenous regressors. Econom. Rev. 34, 82-115.

Dötz, N., Fischer, C., 2010. What can EMU countries' sovereign bond spreads tell us about market perceptions of default probabilities during the recent financial crisis? Discussion Paper Series 1: Economic Studies 2010,11.

Duffee, G.R., 2002. Term premia and interest rate forecasts in affine models. J. Finance 57, 405-443.

Duffie, D., Singleton, K.J., 1999. Modeling term structures of defaultable bonds. Rev. Financ. Stud. 12, 687-720.

ECB, 2014. The determinants of Euro area sovereign bond yield spreads during the crisis. Monthly bulletin, European Central Bank.

Ejsing, J., Lemke, W., 2011. The Janus-headed salvation: sovereign and bank credit risk premia during 2008-2009. Econ. Lett. $110,28-31$.

Erce, A., 2015. Bank and sovereign risk feedback loops. Globalization and Monetary Policy Institute Working Paper 227, Federal Reserve Bank of Dallas.

Fontana, A., Scheicher, M., 2010. An analysis of Euro area sovereign CDS and their relation with government bonds. Working Paper Series 1271, European Central Bank.

Gibson, H.D., Hall, S.G., Tavlas, G.S., 2014. Fundamentally wrong: market pricing of sovereigns and the Greek financial crisis. J. Macroecon. 39, 405-419.

Gray, D.F., 2013. Modeling banking, sovereign, and macro risk in a CCA global VAR. IMF Working Papers 13/218, International Monetary Fund.

Heckman, J., 1981. The incidental parameter problem and the problem of initial conditions in estimating a discrete time-discrete data stochastic process. In: Manski, C., McFadden, D. (Eds.), Structural Analysis of Discrete Data with Econometric Application, 1990th ed. MIT Press, Cambridge, MA, pp. 179-195.

Heinz, F.F., Sun, Y., 2014. Sovereign CDS spreads in Europe: the role of global risk aversion, economic fundamentals, liquidity, and spillovers. IMF Working Papers 14/17, International Monetary Fund.

Hernández de Cos, P., Koester, G.B., Moral-Benito, E., Nickel, C., 2014. Signalling fiscal stress in the euro area - a country- specific early warning system. Working Paper Series 1712, European Central Bank.

Honoré, B., Kyriazidou, E., 2010. Panel data discrete choice models with lagged dependent variables. Econometrica 68, 839-874.

Lall, S., Cardarelli, R., Elekdag, S., 2009. Financial stress, downturns, and recoveries. IMF Working Papers 09/100, International Monetary Fund.

Maltritz, D., 2012. Determinants of sovereign yield spreads in the Eurozone: a Bayesian approach. J. Int. Money. Finance 31, $657-672$.

Manganelli, S., Wolswijk, G., 2009. What drives spreads in the euro area government bond market? Econ. Policy 24, 191-240.

Matheson, T., 2012. Financial conditions indexes for the United States and Euro area. Econ. Lett. 115, 441-446. 
McHugh, J., Petrova, I., Baldacci, E., 2011. Measuring fiscal vulnerability and fiscal stress: a proposed set of indicators. IMF Working Papers 11/94, International Monetary Fund.

Mink, M., De Haan, J., 2013. Contagion during the Greek sovereign debt crisis. J. Int. Money. Finance 34, 102-113.

Monfort, A., Renne, J.-P., 2014. Decomposing Euro-Area sovereign spreads: credit and liquidity risks. Rev. Financ. 18, $2103-2151$.

Mundlak, Y., 1978. On the pooling of time series and cross section data. Econometrica 46, 69-85.

Palazuelos-Martinez, M., 2008. The German economy in the European Monetary Union. Macroeconomic evolution and adjustment. In: Elvert, J., Schirmann, S. (Eds.), Changing Times: Germany in the 20th Century. P.I.E. Peter Long, Germany, pp. 247-270.

Pan, J., Singleton, K., 2008. Default and recovery implicit in the term structure of sovereign CDS spreads. J. Finance 63, $2345-2384$. Reinhart, C.M., Rogoff, K.S., 2011. From financial crash to debt crisis. Am. Econ. Rev. 101, 1676-1706.

Saka, O., Fuertes, A.-M., Kalotychou, E., 2015. ECB policy and Eurozone fragility: was De Grauwe right? J. Int. Money. Finance $54,168-185$

Tagkalakis, A.O., 2014. Financial stability indicators and public debt developments. Q. Rev. Econ. Finance 54, 158-179.

van Roye, B., 2011. Financial stress and economic activity in Germany and the euro area. Working Paper 1743, Kiel Institute for the World Economy.

Vasicek, O., 1977. An equilibrium characterization of the term structure. J. Financ. Econ. 5, 177-188.

Von Hagen, J., Schuknecht, L., Wolswijk, G., 2011. Government bond risk premiums in the EU revisited: the impact of the financial crisis. Eur. J. Polit. Econ. 27, 36-43.

Wooldridge, J., 2000. A framework for estimating dynamic unobserved effects panel data models with possible feedback to future explanatory variables. Econ. Lett. 68, 245-250. 